\title{
THE PRIZE AND THE PRICE OF INDIVIDUAL AGENCY: ANOTHER PERSPECTIVE ON ABORTION AND LIBERAL GOVERNMENT*
}

In the wake of the recent Supreine Court decision in Webster v. Reproductive Health Services, ${ }^{1}$ Americans likely face yet another prolonged political clash over the abortion issue. The dilemmas raised by unwanted pregnancies involve fundamental questions about tlie nature of American government and society, questions which the Suprene Court, state legislatures, and voters must agam address. For example, what are the goals of the Umited States as a political community? What is the status of an individual in that community? What kinds of harm must the law prevent? And who may define a "liarm"? With an eye to the political upheaval $^{2}$ surrounding tlie Supreme Court's recent abortion decision, this Note revisits the question wliether political power should be used to prevent abortion.

* This Note follows a year and a half of serious study and several revolutions in iny thinking about abortion and government. I spent the spring of 1989 involved in the Duke Students For Life, a pro-life group. My first paper, "Abortion and the Sovereignty of the People," took the extreme position that all fundamental rights derive from super-majority eonsent, and that no right, includimg the professed right to abortion, will be protected as fundamental until that consent is secured. The paper is published as a runnerup essay in the Sidney Lewine Essay Contest in HeaLTH MATRIX, Summer 1989, at 53. After educatimg inyself about natural rights philosophy and the United States' tradition of judicial review, I wrote a second paper, "The Responsibilities of Government Regarding Abortion," for Professors Ruth Grant and John Aldrich at Duke Umiversity. Relying on John Locke's theory of government as Judge when individual shortsightedness and partiality prevent just mdividual judgments, $I$ took the position in that paper that government must ensure due weight is given to the fetus' life when abortion is considered-“due weight" meaning that abortion usually is not justified and usually should not be allowed. Still uncomfortable with advocating the use of coercive political power on the question, I delved further and came to the position presented in this Note.

1. 109 S. Ct. 3040 (1989) (Missouri's prohibition on use of public facilities or employees for abortion upheld; test for viability requirement also upheld). The opinions of both Justice Blackunun, dissentimg, and Justice $O$ ' Connor, concurring, foreshadow the continued debate on abortion. Justice Blackınun says: "For today, the women of this Nation still retain the liberty to control their destinies. But the signs are evident and very ominous, and a chill wind blows." Id. at 3079 (Blackmun, J., dissenting). Justice O'Comır explains her limited concurrence saying, "[T]here will be tine enough to reexamine Roe. And to do so carefully." Id. at 3061 (O'Connor, J., concurring).

2. See Ted Gest, The Abortion Furor, U.S. News \& World Report, July 17, 1989, at 18; Merrill McLoughlin, America's New Civil War, U.S. News \& World Report, Oct. 3, 1988, at 23. 
Pro-life activists make the critical assumption that a fetus is a developing human life and, therefore, attempts to destroy it ought to be forcefully prevented. ${ }^{3}$ Pro-choice activists make the equally critical, contrary assumption that even if a fetus is a developing human life, the political community should not value it the same as a born human being for purposes of forceful protection. ${ }^{4}$ Although this fundamental conflict cannot be resolved through a single point of view, both sides of the debate could benefit by considering inore seriously the methods and purposes of moral and political power. ${ }^{5}$ Sensitivity to the difference between moral and political power may lead to more common ground than has appeared possible im the past-even, perhaps, to the opportunity for a peaceful political consensus in the face of deep moral disagreements.

This Note addresses the difference between moral and political power primarily from the vantage point of political theory. The Note mamtains that the decision to have an abortion is an immoral rejection of a voluntarily acquired responsibility to nourish the fetus, and that abortions should be opposed with all the methods of moral power. ("Voluntarily acquired" excludes a pregnancy resulting from rape or incest.) However, because of the importance of moral and religious commitments in the perception of a responsibility to nourish the fetus, individuals should not be coerced by political power to fulfill that responsibility.

For purposes of this Note, "political power" includes the use of physical and econormic pumishments or constraints to coerce conduct. ${ }^{6}$ "Moral power" operates by example, reasoning and persuasion but leaves

3. Bernard Nathanson, ABorting AMERICA 259-60 (1979); McLoughlin, supra note 2, at 27; Mary Meehan, More Trouble Than They're Worth? Children and Abortion, in ABORTION: UNDERSTANDING DifFerences 145, 146-48 (S. Callahan \& D. Callahan eds. 1984).

4. Kristin Luker, Abortion and the Meaning of Life, in ABORTION: UNDERSTANDING DIFFERENCES, supra note 3, at 25, 42; McLoughlin, supra note 2, at 25, 27.

For the purposes of this Note, I coinpare only two categories of human life-fetuses and born human beings. I do not discuss the important question at what point from conception to birth government should begin proteeting life with political power. The Supreme Court presently allows, but does not require, coercive protection of fetal hfe after the point of viability when the fetus "presumably has the capability of meaningful life outside the mother's womb." Roe v. Wade, 410 U.S. 113, 163 (1973).

5. The idea that the legality and morahity of abortion are distinct issues is an argument usually made to support a pro-choice political position in coinbination with varying degrees of unoral condemnation of abortion. See Rosalind Petchesky, ABortion and Woman's Choice: The STATE, SEXuALITY, AND ReProductive FreedoM 348-49 (1985) ("[W]e need to distinguish between the political question-who should decide-and the moral question-whether abortion is right or wrong in a given instance."); Mary Mahowald, Abortion and Equality, in ABORTION: UNDERSTANDING DIFFERENCES, supra note 3, at 177, 178 (noting that some "approve of the legality but not the morality of abortion"); Mary Segers, Abortion and the Culture: Toward a Feminist Perspective in id. at 229, 233 ("fact that abortion is legal is not held to be conclusive of its inorality").

6. John Locke contemplated a similar meaning of political power in his SECOND TREATISE OF GoverNMENT $\S 3$ (C. Macpherson ed. 1980): "Political power, then, I take to be a right of making 
individuals free to act according to their own choices. "Political community" is a community that maintains its bonds by political power and consequently serves a limited purpose among the people or society generally. ${ }^{7}$ "Society" includes the political community as well as communities bound togetler by common interests and coinimitinents not appropriately coerced by political power. "Individual agency," or "individual liberty," refers to the riglit of individuals to govern themselves-to be the final judges of when and low to act on a particular matter.

Part I of this Note explores the capacity for individual agency as the foundation for the separation of inoral and pohtical power. ${ }^{8}$ The first Part concludes, as did the Framers of the Constitution, that existence of this capacity requires respect for individual agency, even if many individuals do not use their hiberty to develop morally good actions and attitudes. 9 Proper respect for individual agency soinetimes requires restraint in the use of political power in favor of moral power.

The Note einphasizes that the goal of moral power need not be inoral relativity or appreciation for diversity on all matters calling for political restraint. One can distinguisl ineaningfully between right and wrong on issues sucli as abortion, while recognizing that the responsibility to do riglit, and the responsibility for botli personal and social consequences of right or wrong conduct, lies witl the individual. ${ }^{10}$

Part II discusses the difficulty of judging whether moral or political power sliould be used to enforce riglit conduct on the abortion issue. The desire to protect the fetus and to mamtain consistency in the political community's treatment of liuman life leads to the conclusion that political power should be used. However, the importance of individual religious and inoral commitments in valuing the fetus relative to other values implies that moral power, not political power, sliould be used. ${ }^{11}$ Further, because forbidding abortion does mucli inore than prevent liarm-it also coerces substantial sacrifices from pregnant women- the use of moral power is inore appropriate than the use of political power. ${ }^{12}$ Finally, the Note argues that full individual responsibility for family and sexual relations requires the exclusive use of noral power, althougli al-

laws with penalties of death, and consequently all less penalties ... and of employing the force of the community ... and all this only for the public good."

7. Locke articulates this meaning of pohtical community. Id. $\$ \S 126-31$; see also Ruth Grant, Locke's Political Anthropology and Lockean Individualism, 50 J. of Politics 42, 51 (1988).

8. See infra notes 18-23 and accompanying text.

9. See infra notes $24-45$ and accompanying text.

10. See infra notes 46-65 and accompanying text.

11. See infra notes 66-106 and accompanying text.

12. See infra notes 107-16 and accompanying text. 
lowing for individual responsibility on the abortion question also allows some adults to settle for less in their moral coinmitments. ${ }^{13}$

Since Roe v. Wade, state legislatures have not been allowed to use political power to coerce individuals in the abortion decision. In Roe, the Supreine Court determined that pregnant woinen, in consultation with their doctors, should be the final judges of how to act when faced with an unwanted pregnancy. ${ }^{14}$ State legislatures cannot infringe individual agency ${ }^{15}$ on the question until a fetus is viable, although a state can regulate the abortion procedure in the interest of the inother's health prior to viability. ${ }^{16}$

In a recent case, Webster v. Reproductive Health Services, several Justices-nainely Chief Justice Rehnquist and Justices White, Kennedy, and Scaha-express discomfort with the level of protection Roe grants to mdividual agency at the expense of the democratic process. ${ }^{17}$ Although they would not prevent a state from protecting individual agency on the abortion question, they also would not prevent a state froin protecting fetal life with pohitical power, at the expense of individual agency. These Justices believe that the values of life and liberty at stake in the abortion dilemma should be balanced in the democratic process. A legislative majority should decide whicli value is paramount and to what extent.

Most of this Note advocates a negative answer to the question whether political power should be used to prevent abortion, without suggesting whicl government institution should answer that question. The discussion about the use of political power applies to state legislatures as mucli as to the Supreme Court. However, the Note's conclusion briefly

13. See infra notes $117-26$ and accompanying text.

14. 410 U.S. 113,163 (1973).

15. The Supreme Court uses the label "right of privacy" for what I refer to as individual agency.

This right of privacy, whether it be founded in the Fourteenth Amendment's concept of personal liberty and restrictions upon state action, as we feel it is, or, as the District Court determined, in the Nmth Amendment's reservations of rights to the people, is broad enough to encompass a woman's decision whether or not to terminate her pregnancy.

Id. at 153. But see John Hart Ely, The Wages of Crying Wolf: A Comment on Roe v. Wade, 82 YALE L.J. 920, 932 (1973) ('I suppose there is nothing to prevent one from using the word 'privacy' to mean the freedom to live one's life without governmental interference. But the Court obviously does not so use the term.").

16. Roe, 410 U.S. at 163.

17. Chief Justice Rehnquist, joined by Justices White and Kennedy, writes for the plurality: "[T]he goal of constitutional adjudication is surely not to remove inexorably 'politically divisive' issues from the ambit of the legislative process, whereby the people through their elected representatives deal with matters of concern to them." Webster v. Reproductive Health Servs., 109 S. Ct. 3040,3058 (1989). Justice Scalia expresses the samc concern unore directly in a separate concurrence: "[O]ur retaining control, through Roe, of what I believe to be, and many of our citizens rccognize to be, a political issue, continuously distorts the public perception of the role of this Court." Id. at 3065. Despite the overtures, Webster does not expressly overrule Roe. Id. at 3058. 
addresses the debate revived in Webster: Whether state legislatures or the Supreine Court should set the bounds of political power on the abortion question. Although state legislatures should endeavor to avoid illegitinnately infringing individual liberty, their actions are properly reviewable by the Supreme Court under the fourteenth amendment. Indeed, the Supreine Court has assuined responsibility since the passage of the fourteenth amendment, by virtue of the characteristics and powers granted it $m$ the Constitution and $m$ the tradition of judicial review, to prevent state governments froin unduly infringing imdividual hiberty. Although the Note suggests some improvements for the analysis in Roe v. Wade, it concludes that the Supreme Court's decision in that landmark case is consistent with the principles supporting our forn of governinent: respect for individual agency and unwillingness to coerce more than a minimum level of morally good behavior.

The Note does not address the many other abortion-related dilemmas that state legislatures and the Supreme Court have faced and will yet face: Whether public funds, employees, or facilities acquired im part from persons deeply opposed to abortion can be used to fund abortions; whether notice of intent to abort must be given to fathers of the fetus; whether notice inust be given to parents of pregnant minors; which regulations of the abortion procedure exceed a state's powers; and whether and to what extent the law should require preguant woinen to refram from drugs and alcohol that harm fetal development. All these issues require separate consideration of the purposes and powers of government in their resolution and are beyond the scope of this Note.

\section{The Separation of Moral and Political Power}

\section{A. Foundation for the Separation: The Capacity for Individual Agency}

If forcing moral conduct would assure right conduct ${ }^{18}$ and still allow imdividuals to develop a sense of responsibility, society would lose nothing by forcing moral conduct. In fact, society would gain. Rather than a world where some do right and some do wrong, with varying degrees of aspiration to do right or wrong, we would have a world where almost all do right. Aristotle saw this potential and argued that compellimg the young to do good would allow some individuals to develop good habits as they mature. Continuing that compulsion into adulthood

18. I am aware of the difficulty of establishing a consensus on what is "right conduct." For purposes of this Part, I am speaking to the individual reader as if we all agreed with her or his judgments of right and wrong to whatever extent she or he inakes those judgments. 
would not burden them and would control the unruly at the same time. Aristotle writes:

For most people are swayed rather by compulsion than argument, and by punishments rather than by $a$ sense of what is noble. This is why some believe that lawgivers ought to exhort and try to influence people toward $a$ life of virtue because of its inherent nobility, in the hope that those who have made good progress through their habits will listen to them. Chastisement and penalties, they think, should be imposed upon those who do not obey and are of an inferior nature, while the incorrigible ought to be banished abroad. ${ }^{19}$

While many may object to Aristotle's proposal, few would contend that his description of human nature is wholly inaccurate. Punishments often do sway mdividuals more than a sense of what is noble. However, the important question remains whether some individuals fail to respond to what is noble because of an "imferior nature" (bestowed by bad genes or improper education) - that is, whether they are incapable of so responding - or because, for a variety of reasons, none of which absolves them of final responsibility, they do not develop the moral capacities possessed by normal, adult human bemgs. ${ }^{20}$ If the former is true, requiring those adults with an inferior nature to govern their lives without the compulsion of external penalties is neither sensible nor kind. However, if the latter is true of adults, then force generally will not encourage the development of desirable attitudes and behavior. Force under such circumstances will do about as much good as moving another's limbs in an attempt to strengthen their muscles for them. Therefore, knowing if all normal adults have the capacity for responsible moral behavior, like knowing if a person has muscles, helps determine whether one encourages others to flex (uses moral power or persuasion) or does all the pulling herself (uses pohtical power or coercion). ${ }^{21}$

19. ARIStotle, Nicomachean Ethics 296-97 (M. Osdwald trans. 1962); see Martin Diamond, Ethics and Politics: The American Way, in THE MORAL Foundations OF THE AMERICAN Republic 75, 80-81 (R. Horwitz 3d ed. 1986) ("Human character, Aristotle argues, can be perfected only within ... the political commumity, and through what it alone can supply, namely, good laws 'with teeth in them' ....").

20. By "normal, adult human being," I mean a not mentally retarded or otherwise severely mentally handicapped adult human being. Although adverse life circumstances will make the lack of moral behavior in normal adults more understandable, under a liberal theory of human nature nothing ean deprive individuals of ultimate responsibility for a lack of wisdom, self control, and love.

21. Professor Ruth Grant points out in her book, JoHN Locke's LiBeralisM 205 (1987), that "[a] just estimation of men's capacities must be the foundation for any theoretical effort that hopes to offer men practical guidance im managing the political problem." She thoroughly discusses John Locke's estimation of humankind's capacity to reason and its implications for the possibility of political theory as well as for individual agency. $I d$. at 12-51. 
Whether individuals use individual agency in a manner compatible with others in the community, and whether they develop themselves well or poorly, are questions that differ from the question whether they have the capacity to do so. If they have the capacity, political power can alleviate and prevent damage from severely antisocial behavior, but only moral persuasion can alleviate or prevent damage from undeveloped abilities and lack of goodness. ${ }^{22}$ Adverse life circumstances may niake failures more understandable, but an adult individual ultimately caimot blame anyone or anything for immoral behavior under a liberal theory of human nature: Human beings are capable and therefore must be free and responsible. The prize of individual liberty is that some individuals will develop their noral capacities in 1 difficult or relatively congenial circumstances, including their capacity for wisdom, care, and responsibility for their own and others' welfare. These individuals will feel and act responsibly to an extent that would not be possible without individual liberty. The price of individual liberty is that some individuals, out of bitterness, fear, ignorance, or love of other things, will not develop their moral capacities and will behave in self-aggrandizing or hurtful ways. The prize cannot be had without the price. ${ }^{23}$ We may have morally right conduct without individual hiberty, but not morally responsible human beings.

No one can prove empirically that individuals who abuse their own freedom of action by damaging themselves and others (in ways that pohtical power may or may not alleviate) are capable of doing better. To assume that they do, contrary to Aristotle, is an experiment of faith in humankind. However, observation, introspection, and experience does give confidence in this assumption and supports the decision to respect individual agency with both its prize and its price.

Recognizing and accepting the price of individual agency should not invite feelings of superiority, separation, or contempt toward others. We owe to each other commitnient, comfort, and patience, however undeserving of them we sometimes may be, as well as an occasional thought-

22. See infra notes $46-65$ and accompanying text (discussing the different purposes of moral and political power). Mill writes, "lt is not because men's desires are strong that they are ill; it is because their consciences are weak." JoHN STUART MILL, On Liberty, in UTILITARIANISM, ON LIBERTY AND CONSIDERATIONS ON REPRESENTATIVE GoverNMENT 69, 127 (H. Arton ed. 1972).

23. See Robert Goldwin, Of Men and Angels: A Search for Morality in the Constitution, in THE MORAL Foundations of THE AMERICAN Republic, supra note 19, at 35 ("The morality most appropriate to the American way . . . is a morality that is moderate, that does not crusade, that accepts the fact that among human beings who are free there will be abuses ...."). 
ful rebuke. This moral duty arises from our equal worth, and our potential for developing voluntary moral behavior. ${ }^{24}$

\section{B. The Separation of Moral and Political Power in the Founding of the United States}

In contrast to Aristotle, the original thirteen colonies based the legitimacy of their revolution partly on a belief, taken froin John Locke's political philosophy, that when political power mappropriately intrudes on individual liberty the people have the riglit to abolish it.

We hold these truths to be self-evident: that all men are created equal; that they are endowed by their Creator with certain unalienable rights; that among these are life, biberty, and the pursuit of happiness. That, to secure these rights, governments are instituted among men, deriving their just powers from the consent of the governed. That, whenever any form of government becomes destructive of these ends, it is the right of the people to alter or abolish it and to institute new government ....25

Obviously, "created equal" does not mean "created the same" in interest or ability. When discussing the cause of factions in society while defending the government described by the Constitution, Janes Madison expressly noted the varying imterests and abilities among persons: "The diversity in the faculties of men, from which the rights of property originate, is not less an insuperable obstacle to a uniformity of interests. The protection of these faculties is the first object of government."26 Rather, "equal" means equal in the possession of faculties suited to individual agency im ordering individual lives.

No matter low mucli individuals differ in interest and ability,27 they do not differ so mucl that as a general matter soine are able to exercise individual agency whereas otliers are not. As Locke emphasizes in his political theory, the most important implication of this assumption for

24. See J.S. MiLl, supra note 22, at 144 ("Human beings owe to each other help to distinguish the better from the worse, and encouragemeut to choose the former and avoid the latter."). In contrast with my position, Mill does allow for separation from and expressions of contcmpt toward others. Id. at 146.

25. The Declaration of Independence para. 2 (U.S. 1776). Professor Mary Ann Glendon compares the American emphasis on individual rights and equality with the European leanings toward social responsibility and moral education in the civil law. Professor Glendon believes Americans have neglected the educational power of the law-that we need to incorporate more of Aristotle's vision into our lawmaking because "law is, among other things, the art of pursuing dignified living, of establishing meaning and constituting community ..." MARY ANN GLENDON, ABORTION AND DivorCE IN WESTERN LAW 142 (1987).

26. The Federalist No. 10, at 78 (J. Madison) (C. Rossiter ed. 1961).

27. Diamond, supra note 19, at 103 ("But the Ameriean political order nonetheless still presupposed that an inequality of virtues and abilities was rooted in human nature and that this inequality would manifest itself and flourish in the private realm of society."). 
political government is that no one, however superior in intelligence, can claim a right to govern others without their consent. ${ }^{28}$ Locke writes:

To understand political power right, and derive it from its original, we must consider, wliat state all men are naturally $\mathrm{m}$, and that is, a state of perfect freedom to order tlieir actions, and dispose of tlieir possessions and persons, as tliey think fit, witlin the bounds of the law of nature, witlout asking leave, or depending upon tle will of any other man.

A state also of equality, wherein all power and jurisdiction is reciprocal, no one liaving more than another; there being nothing more evident, than that.creatures of the same species and rank, promiscuously born to all the same advantages of nature, and the use of the same faculties, should also be equal one amongst another without subordination or subjection . . . .29

Justice Douglas, concurring in Roe v. Wade, articulates the saine principle of individual liberty, or individual agency, using the language of "privacy:"

That riglit [of privacy] imcludes the privilege of an individual to plan his own affairs, for, "outside areas of plainly harmful conduct, every American is left to sliape his own life as lie thinks best, do wliat lie pleases, go where lie pleases."30

The government described in the United States Constitution rests not only on the assumption of equality in the possession of capacities suited to individual agency but also, as Madison suggests in the following exanıle, on the fact that many individuals do not develop their capacity for morally good behavior:

28. Walter Berns, Religion and the Founding Principle, in THE MORAL FOUNDATIONS OF THE AMERICAN REPUBLIC, supra note 19, at 218 ("Being free and equal with respect to natural right, and however unequal they inay be according to any religious doctrine or in any other respect, no inan inay justly rule another without his consent ...."); Diamond, supra note 19, at 103 ("American democracy ... denied the ancient clain of excellence to rule as a matter of right. Now this denial is of iminense inportance because, in contrast with the ancient justification of the political claims of the few, it deeply popularizes the very foundation of political life.").

John Locke's liberalism envisions consent to any form of governinent, such as a deinocracy, oligarchy, or even an hereditary inonarchy, that preserves the life, liberty, and property of individuals as all the natural equality of humankind requires. J. LocKE, supra note $6, \S \S 132-33$; see also R. GraNT, supra note 21, at 123-36 (discussing the practical problein of knowing when individuals have consented to the form of governinent and knowing the extent of their obligation to obey once consent is secure). He does, however, proceed to recommend the separation of powers in a "wellordered commonwealth," J. LockE, supra note $6, \S \S 143-48$, and to discuss principles of "fair and equal representation," id. $\S \S 157-58$. He also einphasizes the residual right of the people to alter "the legislative" if the governinent violates their natural rights. Id. $\S 149$.

29. J. LoCKE, supra note $6, \S 4$ (emphasis in original).

30. Doe v. Bolton, 410 U.S. 179, 213 (1973) (Douglas, J., concurring) (quoting Kent v. Dulles, 357 U.S. 116, 126 (1958) (holding that Secretary of State's denial of passports to persons associated with the Coinmunist party without explicit authorization from Congress is due process violation)); see supra note 15 . 
A zeal for different opinions concerning religion, concerning government, and many other points, as well of speculation as of practice . . . have, in turn, divided mankind into parties, inflamed tliem with mutual animosity, and rendered them mucli more disposed to vex and oppress eacli otlier tlian to co-operate for their common good. ${ }^{31}$

The debates in the Constitutional Convention of 1787 about almost every issue in the proposed Constitution reflected concern for the best way to prevent tyranny (or protect individual agency and representative deinocracy) and avoid anarchy (or avoid widespread abuse of individual agency uncontrolled by organized pohtical power). ${ }^{32}$ The government needed to be organized to protect itself and its citizens froin aminosity, selfishness, and abuse of power-inevitable consequences of individual libertywithout imperiling responsible care for others and the wise exercise of power-also impossible without individual liberty.

Because the government is founded on the principle that "[a]inbition inust be inade to counteract ainbition"33 rather than on principles that depend on public virtue in our leaders, some people have accused the United States of moral purposelessness. Professor Benjamin Barber writes, "The republic worked because it never tried to contrive a center; and thus, by ehciting the assent of the citizenry to this value default, acquired a center after all-in the acquiescence of the people to purposelessness."34 The Anti-Federahsts argued during the debates over ratification of the Constitution that the large republic created by the Constitution "dangerously iguored" the cultivation of virtue essential to the maintenance of hberty, which was ouly possible in snialler, hoinoge-

31. The Federalist No. 10, at 79 (J. Madison) (C. Rossiter ed. 1961).

32. Examples of the delegates' pervasive awareness of the tyranny/liberty tension include: the first resolution in the Virginia Plan as proposed to the Convention-"Resolved that the Articles of Confederation ought to be so corrected and enlarged as to accomplish ... 'common defense, security of liberty and general welfare,' "JAMES MADison, NOTES OF DEBATES IN THE FEDERAL CONVENTION OF 1787, at 30 (A. Koch ed. 1987); the debate whether unity in the executive would lead to or protect against tyranny, id. at 46-47; Benjamin Franklin's warning of the need to guard against the "two passions which have a powerful influence on the affairs of men," the love of power and money, id. at 52; Mr. Sherman's argument against the executive veto "enabling any one man to stop the will of the whole. No one man could be found so far above all the rest in wisdom," id. at 62; and the observation that "[n]otwithstanding the oppressions and injustice experienced among us from democracy; the genius of the people is in favor of it, and the genius of the people must be consulted," id. at 64. See also THE Federalist No. 37, at 227 (J. Madison) (C. Rossiter ed. 1961).

33. The Federalist No. 51, at 322 (J. Madison) (C. Rossiter ed. 1961). Madison says that "government itself [is] the greatest of all refiections on human nature" and if "inen were angels, no government would be necessary." Id.

34. Benjamin Barber, The Compromised Republic: Public Purposelessness in America, in THE MORAL Foundations of THE AMERICAN RePUBLIC, supra note 19, at 53; $c f$. Joseph Cropsey, The United States as Regime and the Sources of the American Way of Life, in id., at 172 (Thus far, there is "[n]o mitigation of modern man's dissatisfaction with the absence of any exaltation, vivacity or high-heartedness from official political modernity as laid down by Hobbes and Locke and, incidentally, embodied in our parchment regime ...."). 
nous, agrarian communities. ${ }^{35}$ And Alexis de Tocqueville warns against the tendency toward niaterialistic individualism at the expense of generosity in the United States:

Men living in democratic times have many passions, but most of their passions either end in the love of riches or proceed from it. ... When all the inembers of a communty are independent of or indifferent to each other, the co-operation of each of them can be obtained only by paying for it . . . .36

From a perspective that suffers the price of individual liberty by allowing morally wrong conduct, the U.S. political project does liave lower sights than did Aristotle, who beheved that "laws can make us good."37 Ideally, government in the United States does not use pohtical power to force a high level of moral virtue-only the minimum necessary for peaceful coexistence. ${ }^{38}$ However, from a perspective tliat emphasizes the prize of individual liberty-responsible, wise, and caring individualsthe U.S. political project aims higher than did Aristotle. Our society is simply not satisfied with right conduct on many matters. We want individually chosen right conduct, or moral goodness. ${ }^{39}$ As Professor Martin Diannond describes it, "the explanation of the puzzling American discrepancy-character formation, but not by use of the laws- will be found . . . in the American idea of what is advantageous and right for humans." ${ }^{40} \mathrm{He}$ further suggests that the founders were confident that at

35. Herbert Storing, What the ANTi-Federalists Were For 19-21 (1981); Robert Horwitz, John Locke and the Preservation of Liberty: A Perennial Problem of Civic Education, in The MoRAl Foundations of THE AMERICAN Republic, supra note 19, at 138.

36. 2 ALeXIS De TOCQUeVIlLE, DemocraCY IN AMERICA bk. 3, ch. XVII, at 228 (H. Reeve trans., P. Bradley ed. 1946); see also Cropsey, supra note 34, at 174 ("We are dissatisfied with ourselves because our regime and life are marked by private striving for the satisfaction of individual goals rather than seeking to attain our individual ends through the mediation of a perfectly social act of provision.").

37. ARISTOTLE, supra note 19 , at 299.

38. Diamond, supra note 19, at 83 ("In place of the utopian end postulated by the ancients, the forced elevation of human character, the moderns substituted a lowered political end, namely, human comfort and security."); Richard Hofstadter, The Founding Fathers: An Age of Realism, in THE MORAl Foundations of THE AMERICAN REPUBdic, supra note 19, at 65 ("One thing that the Fathers did not propose to do, because they thought it impossible, was to change the nature of man to conform with a more ideal system.").

For a discussion of harms the U.S. government does and does not alleviate or prevent with political power, see infra notes 68-72, 107-11 and accompanying text. For examples of arguable violations of the principle that government will not employ political power to force moral goodness, see infra notes 59-61 and accompanying text (discussing religion and politics, the prohibition amendment, and the recent efforts to prohibit flag-burning) and Bowers v. Hardwick, 478 U.S. 186 (1986) (holding that states may criminalize consensual homosexual sodomy).

39. See H.L.A. HART, LAW, LIBERTY, AND MORALITY 58 (1963) ("[W] hat is valuable here [im the domain of morality] is voluntary restraint, not submission to coercion, which seems quite empty of moral value.").

40. Diamond, supra note 19 , at 105. 
least among some people, "the full range of the higher human virtues would have suitable opportunity to flourish ... from religion, education, family upbringing, and simply out of the natural yearnings of human nature." 41

Further, the U.S. political project aims higher than any other modern form of government in the possibility for good commumity, despite the fact that the critics of liberal government often mistake imdividual agency for selfish individualism. Professor Lisa Cahill writes:

In such [liberal] views, persons are seen essentially as free and autonomous agents who come into society to protect self-interest by a series of mutually advantageous agreements. Society or community is thus secondary to the existence of the individual; persons are not social by nature and have no natural obligations antecedent to their free consent. 42

Professor Ruth Grant argues to the contrary:

The opposite of Locke's political individualism, however, is not community, but hierarchy. He is opposing the equality and freedom of men to the idea that there is a natural or divinely ordained hierarchy among then. Lockean individualism therefore is not incompatible with the recognition of the importance of commnnal ties, family associations, and social norms, though it is a critique of authoritarian pohitical communities ${ }^{43}$

An autonomous individual need not give priority to individual values above commumity values, altliougli he or she certainly is free to do so. The significance of autonomy is that all individuals, althougli influenced by their social environment, have the imagination and ability to choose what to value, including commumity, free of political coercion. People are ultimately responsible for what they do and do not become, individually and collectively, as a result of their choice of values.

With politically guaranteed freedom of religion, speech, press, and association, the United States is tle best possible environment for the

41. Id. at 107.

42. Lisa Cahill, Abortion, Autonomy, and Community, in ABortion: Understanding DipFERENCES, supra note 3, at 261, 266; see also Rosanne Kennedy, Feminist Legal Theory: Changing the Subject, at 2 n.5 (1989) (unpublished manuscript available from the author) ("The autonomous individual who gives priority to individual ovcr community values is often called 'the liberal self.' "). Professor Ruth Grant, in her article, Locke's Political Anthropology and Lockean Individualism, supra note 7 , at $43 \mathrm{n} .2$, lists other sources that reflect a similar interpretation of Lockean individualism.

43. Grant, supra note 7, at 51. Professor Grant writes further:

My purpose is to show that at least one classical liberal [Locke] recognized fully the extent to which human beings are social beings, but did not believe that that fact dictated any particular political conclusions... The challenge to the communitarians is to show either that a communitarianism that attacks liberal individualism can nonetheless produce nonauthoritarian communities, or that, if it can't, community is worth the price.

Id. at 43,61 (footnote omitted). 
development of wise, responsible, and caring individuals and communities. ${ }^{44}$ If Americans fail in this opportunity, they fail not from insufficient use of pohtical power, but rather froin insufficient use of inoral power and froin an inability to reach a voluntary consensus on inoral dilemmas, not from moral purposelessness in their government. ${ }^{45}$

\section{The Different Methods and Purposes of Moral and Political Power}

1. Political Power Can Stifle Individual Responsibility and Development. Separating inoral and political power and distinguishing the purposes of each, although the purposes soinetimes overlap, rests on the assuniption that normal, adult hunian beings are capable of inoral responsibility that cannot be coerced; indeed, coercion on some matters stifles the developinent of responsibility. Beliefs regarding religious matters and conimitments to inorally good behavior such as generosity, honesty, and kindness provide examples of attitudes and beliavior that do not develop as a result of the use of force. Although "right conduct" in some instances can be forced, the inner commitinent that inakes moral action meaningful must come from individual, voluntary affirmation.

Coercing adults who will not inake inorally good choices through their individual agency into inaking better clioices usually does not make thein inorally good people. Rather, the coercion often drives thein to rebel against the coercion, or submit without assuming any responsibility for the coerced action. ${ }^{46}$ In eitler case, their judgment has not improved, and their inner commitnient to the better choice lias not been secured. John Locke's description of the inability to secure worthwhile rehigious commitment through coercion illustrates this point:

[T]rue and saving Religion consists in the inward persuasion of the Mind, without which nothing can be acceptable to God. . . . [A]nd Penalties in this case are absolutely impertinent; because they are not proper to convince the mind. ... It is only Liglit and Evidence that can work a cliange in Mens Opinions; which Light can in no manner proceed from corporal Sufferings, or any otler outward Penalties. . . .

44. I write this with confidence and hope as a member of a community aspiring to those ideals-the Church of Jesus Christ of Latter-Day Saints (the Mormons). Although we have our difficulties, as does any community of free agents, I honor my fellow latter-day saints for the depth of their commitment to the complete well-being of others as well as themselves. My respect for the organization, composed of persons of widely-varying interests and abilities, has grown tremendously as I have participated with them in California, Washington, Utah, and North Carolina.

45. See text accompanying note 34. Robert Goldwin writes, "And that conviction, that we are truly a moral nation of moral men and moral women, is essential to our survival and happiness, because of the way we are constituted." Goldwin, supra note 23 , at 39 .

46. Cf. H.L.A. HART, supra note 39, at 21-22 ("The second aspect of legal enforcement bears on those who may never offend against the law, but are coerced into obedience by the threat of legal punishment. ... [I]nterference with individual liberty . . . is itself the infliction of a special form of suffering -often very acute-on those whose desires are frustrated by the fear of punishment."). 
[M]en cannot be forced to be saved whether they will or no. And therefore, when all is done, they must be left to their own Consciences. ${ }^{47}$

Laws that extend too far into the domain of individual agency also deprive adults who would use agency to make inorally good choices of the need to explore different possibilities and thereby develop good judgment. The fit of the laws with their natural inclinations and the ease of following without thinking deeply or discovering why can discourage growth. John Stuart Mill thoroughly discusses this observation in his essay, On Liberty:

He who chooses his plan for himself, employs all his faculties. $\mathrm{He}$ must use observation to see, reasoning and judgment to foresee, activity to gather materials for decision, discrimination to decide, and when he has decided, firmness and self-control to hold to his deliberate decision .... It is possible that he might be guided in some good path, and kept out of harm's way, without any of these things. But what will be his comparative worth as a human being? It really is of importance, not only what men do, but also what manner of men they are that do it. ${ }^{48}$

Sometimes governinents should refrain from using political power to force decisions on mdividuals when the state lacks confidence in the universality of the answers, but that is not the only occasion. Sometimes the state should refrain because the decisions require voluntary affirmation to be ineanimgful. When "right" entails individual commitments to concern for others or deference to God, for example, people cannot be forced to assume these commitments. ${ }^{49}$ The individual, not family members, communities, or governinents, should answer questions that require such commitments because the most important consequence in answering them, among other consequences, is an individual's acceptance or rejection of deeply binding obligations. ${ }^{50}$

2. Moral Right Without Political Enforcement. Refraining from the use of political power to force inoral behavior does not always entail abandoning the truth of the inoral principles. On sonie inatters left to individual agency, such as career interests or musical tastes, appreciation for diversity is a good in itself. ${ }^{51}$ On other inatters, pluralism inay not be

47. JOHN LOCKE, A LetTer CONCERning TOLERATION 27, 38 (J. Tully ed. 1983).

48. J.S. Mill, supra note 22, at 127; see also R. GRANT, supra note 21, at 194 ("And to be truly free, he must be guided by his own reason. It is not enough to do the reasonable thing. A man must have reached the conclusion on his own that it is the reasonable thing to do.").

49. J.S. MiLL, supra note 22, at 85, 134-35.

50. See id. at 151 .

51. Mill distinguishes between moral and political power in the project of making human beings good, but also carves out a large domain of individual agency that should not be disturbed by coercion or moral condemnation. J.S. MiLl, supra note 22, at 123-42. 
the highest good. Professor Robert Goldwin writes: "[T] practical or political morality] is to make the moral judgment, to recognize evil as evil, and not look the other way, or refuse to judge (on relativistic grounds), or shrug our shoulders and say we 'don't care." "52

The variety of opinions notwithstanding, a person can believe in right and wrong answers to moral questions, including the question whether or not to abort a fetus. Individuals may struggle to discover the right answers since no moral code can account for all the variations $m$ real circuinstances, and they may struggle even more to adhere to the answers they have discovered. ${ }^{53}$ However, this observation need not dissolve one's thinking into "ethical relativisın," if that term means that whatever individuals may clioose for themselves is right because of the struggle involved in choosing. ${ }^{54}$

Feminist scliolar and theorist Rosalind Petchesky mistakes the moral position that abortion is wrong for a demal of individual responsibility on the abortion issue:

52. Goldwin, supra note 23 , at 36 . The second step is to decide whether to use moral or political power to address the evil. See id. Professor Gordon Wood expresses the hope of some of the Founders that the diversity of opinions colliding freely in society would lead to "the ultimate triumph of Truth." Wood, The Democratization of Mind in the American Revolution, in THE MORAL FOUNDATIONS OF THE AMERICAN REPUBLIC, supra note 19, at 133.

Rosalind Petchesky warns against the dangers of absolutism and states that it is "false to link relativism irrevocably with amorality." R. PETCHesky, supra note 5, at 329. She suggests that all "moral, legal, and philosophical questions" are subject to "historical and cultural variations." Id. While there is room to learn restraint and appreciation for context from her without abandoning moral truth on some matters, she ultimately disagrees that abortion is one of those matters. Id. at $366-67,374$.

53. R. GRANT, supra note 21, at 180 ("We cannot know all things with certainty, and the principles that we can know do not automatically govern our behavior."); see Petchesky, supra note 5 , at 365 (citing recent attitude surveys showing the disjunction between abortion beliefs and practices).

54. See Segers, supra note 5, at 251-52 ("A commitment to the availability of legalized abortion need not bind one to a kind of casual ethical relativism. ... I beheve that femirists can and should define the moral standards and principles against which to measure our behavior with respect to abortion.").

Rosalind Petchesky describes the "morality of praxis" in her book, ABORTION AND WOMAN's Choice: The State, Sexuality, ANd Reproductive Freedom, supra note 5, at 364-74. A popular way of expressing the extreme form of the "morality of praxis," or contextual morality, on the abortion issue is that every individual must exercise moral judgment about abortion, but no one can tell another individual that their decision is right or wrong. Id. at 333 (quoting a Baptist clergyman) ("Abortion presents a matter for individual moral decision ...."); see also Luker, supra note 4, at 44 ("[P]ro-choice people tend to see ethical issues as matters of individual conscience, guided by moral principles, rather than as moral codes per se. Hence, the emphasis that pro-choice people put on abortion as an individual, private choice."); McLoughlin, supra note 2, at 29 ("It's a permanent decision ... . I don't think that anyone has the right to say, 'You have to do it this way.' ").

Although she would never support references to general, categorical right and wrong, Rosalind Petchesky does recognize some limitation to private morality regarding abortion. For example, she writes that aborting "solely on the basis of gender preference" is "immoral." R. PETCHESKY, supra note 5 , at 349 . 
Abortion is wrong, in their view, not only because it "destroys innocent life," but even more because it rests on and validates a principle of morahity that assumes that imdividuals must make clioices for themselves and ought to do so in terms of the concrete situations in which they hive. 55

Not all pro-life individuals conclude that contextual morality is wrong as a matter of principle, although they conclude that aborting a fetus rarely is moral in any context. In the dilemmas people face every day, "right" and "wrong" are a function of a person's intentions, her judgments about how best to realize those intentions, and the effects of her resulting action on herself and others. Meaningful morality cannot be anything but contextual. Realizing this, family therapist Theodora Ooins aptly describes the difficulty of applying moral values to specific situations:

Moral values--such as the need to preserve and protect life- are ideals to strive for. In concrete moral situations, they nearly always have to be weighed against other, conflicting moral values. They serve as primciples to be applied differently to different situations, and the consequences of applying them also need to be taken into account. ${ }^{56}$

Although I agree with Ooms' assessment of the general difficulty, I do not share her view that the responsibility for beginning life and the moral claims of the fetus to continued hfe do not outweigh almost all other considerations. Sorne intentions and the means to accomplish thein are universally better, in a moral sense, than others. I submit that accepting the possibility of pregnancy from heterosexual intimacy and determining to nurture the fetus should pregnancy occur is a better decision than engaging in sexual intimacy and then deciding to abort a fetus that may be conceived. Abortion is an immoral rejection of the mutual responsibilities of two individuals to a developing fetus, responsibilities that were voluntarily acquired. ${ }^{57}$ I do not shight the gravity and difficulty of the struggle faced by women and men who deal with unwanted pregnancies, or the need to allow individuals to inake their difficult choices free from pohtical coercion, as discussed below. However, I contend that principles not appropriately enforced by political power may still be the right principles on which individuals should make their

55. R. PETCHESKY, supra note 5, at 379.

56. Theodora Ooms, Commentary to Chapter 6 , in ABortion: Understanding DifferENCES, supra note 3, at 171, 172.

57. Unfortunately, the purpose of this Note will not allow a full defense of my moral position, but see infra text accompanying notes $97-99$ for a slightly longer statement. Although she advocates coercive prevention of abortion, Mary Meehan provides a concise moral statement for valuing the fetus even in grave social, emotional, and financial circumstances, and even if the fetus is handicapped. Meehan, supra note 3, at 151-68. 
choices regarding abortion. The individual and collective struggle to know and adhere to these principles is the domain of moral power.

Refraining froin political coercion on moral questions should not also mean abandoming the public struggle over issues such as abortion. Moral power cannot operate properly, and individuals cannot develop fully, without using every channel available to persuade mdividuals to make right choices on moral issues, and this includes public speaking and writing. Mill offers msight concerning the importance of using persuasion as an aspect of moral power:

In the case of any person whose judgment is really deserving of confidence, how has it becoine so? Because he has kept his unind open to criticism of his opinions and conduct. ... No wise inan ever acquired his wisdom in any mode but this; nor is it in the nature of human intellect to become wise in any other manner. . . Instead of any diminution, there is need of a great increase of disinterested exertion to promote the good of others. But disinterested benevolence can find other instruments to persuade people to their good than whips and scourges, either of the hiteral or the metaphorical sort. ${ }^{58}$

3. No Bright Lines Here. Securing peaceful, purposeful human commumity depends on choosing well when political power is necessary to ensure that individuals live peaceably in pohitical community and when the use of political power is mappropriate. Often persons' strong religious and moral commitments have spilled over into pohtical activity in America. ${ }^{59}$ Members of the First Congress believed rehigion was essential to the preservation of morality, which was, in turn, essential to the preservation of hiberty. Consequently, they expected the states to continue to foster rehgion over non-rehigion by public assistance and ex-

58. J.S. MiLL, supra note 22 , at $88,144$.

59. In his dissent in Poe v. Ullman, Justice John Harlan reasons from an unexamined assuinption that the State has soine "rightful concern for its people's moral welfare":

The right of privacy most inanifestly is not an absolute. Thus, I would not suggest that adultery, homosexuality, fornication and incest are immune froin crininal enquiry, however privately practiced. So much has been explicitly recognized in acknowledging the State's rightful concern for its people's inoral welfare. But not to discriminate between what is involved in this case and either the traditional offenses against good morals or crimes which, though they may be committed anywhere, happen to have been committed or concealed in the hoine, would entirely misconceive the argnment that is being made.

367 U.S. 497, 552-53 (1961) (citation omitted). For a discussion of the duty judges have to inake the reasoning behind their assumptions explicit, see Katharine Bartlett, Feminist Legal Methods, 103 HARV. L. REV. 829, 862-63 (1990).

Ironically, Justice Harlan's emphasis in Poe on protecting private marital relations from government intrusion is ignored by the Supreme Court in later cases. These cases trumpet Justice Harlan's dissent in support of a general right to sexual and reproductive privacy for all individuals regardless of marital status. E.g., Griswold v. Comiecticut, 381 U.S. 479, 495 (1965) (Goldberg, J., concurring) (access to contraceptives); Roe v. Wade, 410 U.S. 113, 169 (1973) (Stewart, J., concurring) (abortion). 
ample, while somehow remaming neutral among religions. ${ }^{60}$ Current disagreements over matters such as school prayer, nativity scenes on public property, and tax exemptions for churches are evidence of the difficulty involved im judging when and how to use political power with respect to rehigion. Another example, the doomed prohibition amendment, partly stemmed from some imdividuals' aspiration to use political power to mstill higher ideals in other individuals. ${ }^{61}$ For some, the recent attempts to prohibit flag-burning represent a similar aspiration.

Part of the difficulty in judging when to use political rather than moral power stems from the realization that on sone level, all laws regulate moral behavior. Laws regulate relationships between people that involve an obligation to do or refrain froin doing certain things. Stealing money from a busmess partner, failing to pay taxes, driving over the speed limit, sexually abusing a clild, or killing another person all involve immoral conduct that the political community refuses to tolerate without regard for the moral commitments, or lack of commitments, of the individuals imvolved.

Further, almost all behavior imphicates moral concerns of some kind. Human beings are inescapably interdependent. Everything we do or fail to do affects the people with whom we live and work. ${ }^{62}$ The same action may both benefit some and harm others, depending on the values and perspectives of those individuals affected by it. The political community must choose which harms it will prevent and alleviate with coercive political power and which should be left to the conscience and agency of individuals and their communities.

60. Berns, supra note 28 , at 207-14.

Abraham Lincoln also teaches that American democracy needs civil religion, see Michael Zuckert, Locke and the Problem of Civil Religion, in THE MORAL Foundations OF THE AMERICAN REPUBLIC, supra note 19, at 181, and Tocqueville writes that "provided the citizens profess a religion, the peculiar tenets of that religion are of little importance to [society's] interests." $1 \mathrm{~A}$. DE TOCQUEVILLE, supra note 36, ch. XVII, at 303.

John Locke also was convinced that religious activity of some kind is necessary for peaceful coexistence in political commumity. He would have supported political intolerance of atheists in tandem witl religious liberty to all believers. Locke, supra note 47, at 51. The United States political community disagrees with Locke on that point, U.S. CONST. amend. I; e.g., Wallace v. Jaffree, 472 U.S. 38, 52-55 (1985) (reaffirming that individual freedom of conscience protected by the first amendment embraces the right to select any religious faitl or none at all), but not because we all do or do not believe religion essential for knowledge of truth or the attainment of liuman excellence. We may believe religion is essential to these ends and yet agree that religion slould not be coerced for two reasons: The coercion is not necessary for peaceful political coexistence, as Locke mistakenly thought (atheists can live up to their obligations as well as any religious individual), and because the attainment of luman excellence demands freely-considered commitment. Therefore, forcing right conduct that prevents freely considered commitment will not do.

61. U.S. CoNST. amends. XVIII, XXI.

62. J.S. MILL, supra note 22, at 148. 
Clear rules that eliminate the need for continual reexamination and good judginent on this choice do not exist. ${ }^{63}$ However, the two step analysis applied in Roe v. Wade ${ }^{64}$ to decide whether abortion causes a harm that should be prevented with political power threatens a confusing polarization of individual interests, or "fundamental rights," agamst "compelling state interests." A liberal constitutional governinent such as we have in the United States has a compelling niterest in the preservation of individuals in the appropriate exercise of individual agency. ${ }^{65}$ The inportance of agency in huinan developnient, as well as the gravity and nature of the potential harm threatened by the lack of political coercion, should guide the political community in naaking the choice whether to prevent or alleviate a given harm through the use of political power.

\section{The Abortion Debate}

The importance of individual agency and assuniptions about human potential and huinan responses to coercive power have guided the American government in its use of political power. ${ }^{66}$ These sane considerations should guide the debates about abortion. The abortion dilemma perhaps deniands greater sensitivity to the difference between moral and political power than any other current issue because of the significance of

63. Professor Ruth Grant counsels government actors making such choices in her discussion of Locke's epistemology and political theory:

[W] hile certain knowledge of true standards of behavior is possible, it is difficult and re-

quires that we use our rational faculties well. And even then, such knowledge of abstract

principle is not sufficient by itself. ... Even when the principle or the rule is clear, a

judgment must often be made as to whether it applies to the circumstances in question,

whether a given thing or action belongs to the categories included in the rule.

R. GRANT, supra note 21 , at 49.

64. 410 U.S. 113, 155 (1973) ("fundamental rights" can be limited only by a "compelling state interest").

65. "Liberal" in this context does not mcan the opposite of "conservative" as used in current political discourse. It refers to a government founded for the purpose of preserving individual liberty, such as Locke describes in his writings. Professor Ruth Grant explains: "Locke's is a dual standard. One element cannot be elevated above the other, and there is no need to choose between them. Both preservation and freedom are necessary conditions for legitimacy [im liberal government], while neither alone is sufficient." $R$. GRANT, supra note 21, at 97-98. For a full discussion of the relationship between freedom (individual agency) and the preservation of individuals in liberal government, see id. at 88-98.

66. For example, in Zablocki v. Redhail, the Supreme Court strikes down Wisconsin's attempt to encourage the payment of child support by preventing remarriage until the parent provides evidence that the obligation is being met. The Court says a direct prohibition on marriage unreasonably infringes individual liberty. 434 U.S. 374, 389 (1978). In Shapiro v. Thompson, the Court reaffirms that "the nature of our Federal Union and our constitutional concepts of personal liberty unite to require that all citizens be free to travel throughout the length and breadth of our land uninhibited by statutes, rules, or regulations which unreasonably burden or restrict this movement." 394 U.S. 618, 629 (1969) (waiting-period requirement before new-comers receive state public assistance violates equal proteetion). For a discussion of the rejection of Good Samaritan laws in the American legal system, see infra notes 107-11 and accompanying text. 
the values in tension: protection of life and protection of individual agency in deeply personal matters. ${ }^{67}$ Whether to include the fetus in the political community and protect it with the same protection provided each human being who is born requires consideration of the nature of the harm caused by abortion, whether prohibitimg abortion merely prevents harm or also coerces sacrifices in behalf of the fetus, and whether we desire morally responsible human beings or instead would settle for right conduct without regard for mdividual commitments on this inatter.

\section{A. The Nature of the Harm in Abortion}

John Stuart Mill writes that respect for individual agency ends when "there is a definite damage, or a definite risk of damage, either to an individual or to the public."68 But if "damage" includes spiritual damage, and assuming the failure to worship spiritually damages individuals, then we would not have the first amendment. If it includes emotional daniage to public figures, then our libel laws would look different. And if it includes symbolic damage to governmnet authority, perhaps we should curtail expressive freedoin with a flag-burning amendment.

Respect for individual agency requires tolerance for sonie kinds of suffering brought about by wrong choices. "Definite damage" must have a inore restricted ineaning than general human suffering to work as an appropriate limitation on individual agency. Constitutional scholar Walter Berns paraphrases Thomas Jefferson's suggestion for the kind of dan1age the government should alleviate or prevent with coercive power: "Americans are not entitled to regard it as an injury-or an injury for which the law will provide a remedy-for their neighbors to say there are twenty gods or no God. Such rehigious opinions neither pick their pockets nor break their legs ...." 69

Causing physical damage to persons and property has been a punishable crime in this country for centuries. ${ }^{70}$ Some less tangible harnis,

67. Researcher Gilbert Steiner writes: "Abortion can be counted on to be the dominant familyrelated public problem for the indefinite future, and the one the policy process is least likely to resolve, because neither side is comfortable with less than total victory, each side views its cause as sacred, and both are right." Gilbert Steiner, The Futility of Family Policy 71 (1981) quoted in, M. GLENDON, supra note 25 , at 40 .

68. J.S. Mill, supra note 22, at 150; see also LocKE, supra note 6, at 9 ("Every one, as he is bound to preserve himself . . . may not, unless it be to do justice to an offender, take away, or impair the life, or what tends to the preservation of the life, the hiberty, health, hinb, or goods of another.").

69. Berns, supra note 28 , at 217 (paraphrasing 4 THOMAS JefFerson, THE WORKS OF THOMAS JEFFERSON 78 (P. Leicester Ford ed. 1904)).

70. Murder, assault, battery, rape, larceny, embezzlement, burglary, and robbery are some familiar examples. 
such as harm resulting from racial segregation, ${ }^{71}$ also have become punishable, and courts increasingly award civil damages for "intentional infliction of emotional distress." 72 One need not delve further into the always evolving legal definitions of punishable and compensable harm to recognize the difficult judgments required to decide whether political power should alleviate or prevent harm of one kind but not another.

Much of the abortion debate revolves around the nature of the harm done when a woinan aborts a fetus. ${ }^{73}$ Obviously, the damage to the fetus is coinplete and irrevocable: Abortion destroys something that would have developed into a born human being. However, this observation does not answer the question whether the political community should value the fetus to the same extent as a born human being and thus prevent its destruction with coercive power. The observation leaves open the question whether abortion causes a kind of harm that the political conımunity should not tolerate. ${ }^{74}$ This issue differs from whether individuals should value the fetus the saine as a born human benig because of the additional concern for individual agency that forms the foundation of our political community.

As discussed above, our common commitment in the political community necessarily falls far below our human potential for moral goodness. Indeed, because our political commitinents are enforced by

71. Brown v. Board of Educ., 347 U.S. 483, 494 (1954) ("To separate [Blacks] from others of similar age and qualifications solely because of their race generates a feeling of inferiority as to their status in the community that may affect their hearts and minds in a way unlikely ever to be undone.").

72. See Restatement (SeCOND) OF TORTS § 46(1) (1965). ("One who by extreme and outrageous conduct intentionally or recklessly causes severe emotional distress to another is subject to liability for such emotional distress ....") The evolution of this tort from special application in cases of assault or for conduct on a common carrier, as reflected in the 1934 version of the RESTATEMENT OF TORTS $\S 46$, is described in George Christie, CASES AND Materials on the LAW of TORTS $905-24$ (1983).

73. By "harm," I refer to the nature of the wrong, if any, in abortion, not the emotional or physical harm to women that pro-life advocates document, see Brief Amici Curiae on Behalf of Feminists for Life et al., Webster v. Reproductive Health Servs., 109 S. Ct. 3040 (1989) (No. 88-05), and pro-choice advocates dispute, see R. PETCHESKY, supra note 5, at 367.

74. I ultimately conclude that abortion is not one of the causes of suffering the political community should eradicate. See infra notes 103-06 and accompanying text. By "suffering," I mean the moral and emotional suffering of those persons who struggle with the realization that others actually would kill the unborn, and any suffering experienced by the fetus. By contrast, Professor Lisa Cahill uses the inescapability of suffering - the suffering borne by a pregnant woman-to conclude that abortion usually should not be allowed:

The hiberal ethos discourages making personal sacrifices and encourages at best a minimal appreciation of the virtue and even the necessity of constructive suffering. .... [S]ome human situations have unavoidably tragic elements and that to be human is to bear these burdens. We eannot be freed from all infringements on our self-fulfillment, and to persistently demand that is to avoid moral agency in the complete sense.

Cahill, supra note 42, at 271-72. 
coercive power, we must limit them in order to realize a greater degree of individual and collective moral goodness. Therefore, regardless of how we ultimately answer questions such as those posed by abortion, we must consider them carefully with the pohtical/moral power distinction in mind.

Pro-choice advocates sometimes have emphasized that a fetus is not "human life" but rather the "potential" for human life. As such, they argue, it can be treated as no more tlian a tumor or a tissue growth and removed if desired. ${ }^{75}$ According to this perspective, the "liarm" (if any) in abortion is no concern for the political community. Some pro-life advocates, on the other liand, liave gone to tlie opposite extreme and personified the fetus, acting as if it lacks only a voice, which they willmgly provide, and calling abortion murder. ${ }^{76}$

Botli extremes distort reality. On the one liand, a developing fetus with a umque genotype that will become a human being if undisturbed differs siguificantly from a tumor. Free-lance writer Mary Meehan posits:

And there is a special unfairness in penalizing the unborn for not having size or abilities, which if left alone, they will surely develop. It is almost like saying, "In another few inonths, you will grow to the point where we cannot kill you because you will be too inuch like us. Therefore, we will end your lives now ...."77

On the other hand, until tlie poimt of viability, a developing fetus lacks not only a voice, but otlier mental and physical capacities that make an individual. Femimist theorist Rosalind Petcliesky articulates this view:

The inost striking fallacy in the genetic arguments of anti-abortionists is their leap from the fact of genetic individuality ... to the value of human personhood. This is a problem, in part, of confusing the self, the person, with her or his genetic basis, ignoring the enormously com-

75. See Jean Elshtain, Reflections on Abortion, Values, and the Family, in ABORTION: UNDERSTANDING DIFFERENCES, supra note 3, at 47, 50 ("Examples of discourse that aim to distance us ... include arguments that construe the fetus, variously, as a 'parasite,' a 'tenant,' an air-borne 'spore,' or 'property.' "); Mahowald, supra note 5, at 179 ("[A] genuinely pro-abortion position emphasizes ... the fetus is in reality an invasive growth, like a wart or a tumor.").

76. See John Noonan, JR., A Private Choice: Abortion in America in the Seventies 171 (1979) ("When the mask is lifted from the liberty of abortion, it is seen that the liberty consists in a freedom to knife, poison, starve, or choke a human being differing only in his or her degree of helplessness ....") quoted in R. PETCHESKY, supra note 5, at 331; Meehan, supra note 3, at 147 ("It is a violent act, one that usually involves dismemberment of the human embryo or fetus. . . But the violence of abortion, though important, is secondary to the fact that it ends a human life."). Contra R. PETCHESKY, supra note 5, at 328 ("idea that abortion is 'murder' and you are 'killing a baby' is a culturally generated one, not shared by many eras and peoples").

77. Meehan, supra note 3 , at 150 . 
plex interaction between genes, environment, and development that ultimately determines who or what an actual person becomes. ${ }^{78}$

On the most basic level, a developing fetus differs significantly from a born human being in the complete symbiotic relationship with another body necessary for its survival.

Greater scientific evidence will not improve the lack of consensus on the fetus' relative value or on the gravity of the harm involved im abortion. We already know a lot. Even junior high school students are taught that froin the moment one sperm penetrates the ovum, a series of rapid divisions begins a progression of development-heartbeat at eighteen days, brainwaves at forty-two days, all organs formed by the ninth or tenth week. ${ }^{79}$ Unless disturbed by natural or artificial forces, this union of sperm and ovun will become a hunıan being capable of existing outside the uterus. Some persons on both sides of the abortion debate are wilhing to agree that conception and implantation in the uterus is the most definite point to identify the beginning of human hife. Nevertheless, both sides contniue to disagree about the role of the government in forcefully preventing abortion..$^{80}$ As psychologist Sidney Callahan asks poignantly, "How can it be that so many wise and good people can know all the sanie facts, be familiar with all the same arguments, and yet reach different conclusions"'? ${ }^{81}$ Sounething more than biological reality affects one's evaluation of the harm involved in abortion. A value judgment, not a scientific determination, enables nidividuals to decide whether aborting a fetus is acceptable or not. Differences in individual comnitment to religious or moral principles goes a long way in explaining the difference in value judgments. The following descriptions illustrate how different attitudes toward sex and pregnancy correspond to different evaluations of the fetus.

78. R. Petchesky, supra note 5, at 337. Rosalind Petchesky thoroughly discusses the importance of the consciousness of relationship in making us human. Id. at 344-46.

79. Pregnancy Resource Center, Grand Rapids, Mich., Making an INformed DeciSION About Your Pregnancy (1988) (pamphlet).

80. Compare R. PetChesky, supra note 5, at 337-38 ("It might be conceded that the fetus is a form of life insofar as it is alive (as established by EEG readings, heartbeat, and other biological responses) and it is human.... [But this] does not move us one step toward knowing what value to give the fetus ....") with Meehan, supra note 3, at 149, 151 ("Medical and scientific textbooks affirm that the life of each human begins at fertilization (conception).... If their right to life is not recognized and protected, then they are completely vulnerable to power and violence and death.").

81. Sidney Callahan, Value Choices in Abortion, in Abortion: Understanding DifferENCES, supra note 3, at 285, 287. Sidney Callahan, who is pro-life, asks that question from a unique vantage point. For over 30 years, she has been married to Daniel Callahan, who also speaks and writes regularly about abortion from the pro-choice perspective. Together they organized and edited the book, ABortion: Understanding DifFerences. A dialogue between them is printed in Friendly Persuasion, U.S. News \& World Report, Oct. 3, 1988, at 30-31. 
If conception involves inore than matter and natural forces, and a soul pre-exists conception and enters the developing body at soine point before birth, ${ }^{82}$ or if God spontaneously gives spirit to the developing body at soine point before birth, ${ }^{83}$ then we would need to know when that occurred to avoid the substantial harm caused by prematurely disembodying the soul. However, beliefs about ensoulment are inextricably bound up with rehioious beliefs, ${ }^{84}$ which should not be enforced by political power. ${ }^{85}$ Even if true, religious behiefs about human beginnings inust be considered and accepted or rejected as premises for action by free individuals if they are to have any meaning or power in individual lives.

Juxtaposed with those who conclude that abortion is a sin alinost as grave as murder, are those who say that abortion is inore than the better of difficult alternatives-it is not a harm at all, but a positive good in inany circumstances. Feminist theorist Rosalind Petchesky argues for this position:

The view of abortion as a necessary evil born out of desperate circumstances is a liberal accommodation to recent waves of anti-abortion (and anti-feminist) ideology. ... The "necessary evil" concept oddly forgets the spirit of buoyancy infusing not only ferninists but masses of women after Roe v. Wade. . . From this perspective, abortion conducted under safe, affordable, and stigma-free conditions is neitler a necessary evil nor a matter of private cloice. Rather, it is a positive benefit that society has an obligation to provide to all who seek it, just as it provides education and health benefits. ${ }^{86}$

82. Mormons, for instance, believe that each individual has existed forever as a conscious being; that similar to energy/matter, intelligence (or consciousness) cannot be created or destroyed, see Doctrine and Covenants of the Church of Jesus Christ of LatTer-Day Saints 93: 29 (1981 ed.), but only improved by acquiring spirit bodies (fine matter) as literal children of a Heavenly Father and Mother before mortal life, and then bodies of fiesh and bone as children of parents on Earth. They believe that although individuals teinporarily "die" (their spirits return to their prebirth form) all individuals will eventually "resurrect" into tangible bodies of fiesh and bone that can never die thereafter, such as those possessed by our Heavenly Father and Mother. Id. at 130: 22; see also Ezekiel 37: 11-14 (analogy between the regathering of Israel and the resurrection); 1 Corinthians 15: $51-54$ (discussing resurrection).

83. The Catholic Church, for instance, teaches that God creates life: "Human Life is precious because it is the gift of a God whose love is infinite, and when God gives life, it is forever." Pope John Paul II, Homily at Mass in Washington, D.C., N.Y. Times, Oct. 8, 1979, at B6, guoted in Meehan, supra note 3, at 148. For a discussion of historical changes in Catholic beliefs and teachings about ensoulnent and abortion, see Webster v. Reproductive Health Servs., 109 S. Ct. 3040, 3082-84 (1989) (Stevens, J., concurring and dissenting in part).

84. R. PETCHESKY, supra note 5, at 329, 332; Cahill, supra note 41, at 270.

85. U.S. CoNST. amend. I; Virginia Abernethy, Children, Personhood, and a Pluralistic Society, in ABORTION: UNDERSTANDING DIFFERENCES, supra note 3, at 117, 133 ("The debate, one finds, is not just about when biological human life acquires the rights associated with personhood. The debate is about whether this nation shall depart from its constitutionally designed heritage of separation of Church and State."). But cf. Cahill, supra note 42, at 263 ("I dissent froin the proposition that abortion is a narrowly religious issue.").

86. R. PETCHESKY, supra note 5, at 386-87. 
Still other people oppose abortion not for religious reasons, but rather because they place great importance on the life-giving potential of heterosexual sex. ${ }^{87}$ In some circumstances, these people may refrain from sex to avoid altogether the possibility of pregnancy. Or if they engage in sexual intimacy, with or without usimg birth control, they do so fully prepared to assume responsibility for a pregnancy that might result. ${ }^{88}$ People with these perspectives value a fetus as a hiving, developing human being and consider it an unjustified harm, with few exceptions, to cut off fetal development. ${ }^{89}$

People who assume this level of responsibility for the life-giving potential in sex do not necessarily appreciate the potential for pleasure in sex less than others, as is sometimes suggested. ${ }^{90}$ Rather they seek inner peace and fulfillment by subordinating their uninhibited pleasures to the duties those pleasures potentially create. Psychologist Sidney Callahan supports this view:

[I]n the synthesis proposed, sexual expression as an erotic manifestation of love and unity is equal in value to sexuality as procreative. Neither dimension can be denied or discarded or can displace the other in iniportance.... Excitement, love, and enrotional fulfillment may be necessary for the good life, constant sexual expression is not. When hunian beings can have access to niany other enrotional joys and pleasures equal to sex, then it is possible to preserve the procreative diniension inherent $\mathbf{n} ı$ human sexuality by reserving sexual expression for procreative contexts of commitment and love. ${ }^{91}$

Others emphasize, sometimes under the angnishing weight of incompatible concerns $i m$ the event of an unwanted pregnancy, that conception is more appropriately attributable to natural forces or chance than to a deliberate decision to engage in sexual relations. ${ }^{92}$ To them,

87. Callahan, supra note 81, at 287-93; cf. Meehan, supra note 3, at 149 ("Yet, the absence of religious belief does not remove all support from the notion of human rights. . . . Other people still exist, and their very existence imposes obligations on us, just as our existence imposes obligations on them.").

88. Callahan, supra note 81 , at 288; Luker, supra note 4 , at 33.

89. Callahan, supra note 81 , at 291,295 ("Stopping a pregnancy is in the same category of act as stopping any dynamic, ongoing human life."). Contra R. PETCHESKY, supra note 5 , at 341 ("The doctrine of fetal personhood . ... demeans pregnant women, who are treated in this perspective as the physical vessels for genetic messages rather than responsible moral agents. Motherhood in this sense becomes, not a socially determined relationship, but a physiological function . . ..").

90. Summarizing from her five-year study of pro-life and pro-choice activists, Kristin Luker says that for pro-life people "a commitment to amative sex [sexual activity whose goal is sensual pleasure and mutual enjoyment] is at odds with a primary commitment to mothering." Luker, supra note 4 , at 33 .

91. Callahan, supra note 81 , at 289-90. Sidney Callahan accepts contraception and voluntary sterilization as "acceptable means to further the nurturing potential of a committed procreative pair." Id. at 289.

92. R. Petchesky, supra note 5 , at 336. 
conception is a happy or unhappy by-product of sex, but a by-product nonetheless. Although this view admits that a fetus deserves weighty consideration, ${ }^{93}$ no one need feel unduly bound by the joining of sperm and egg which might occur even despite reliance on birth control. A sincere desire to avoid or postpone parenting, commitments to personal goals or to already-existing relationships (including other children), financial or emotional insecurity, and other factors could justify terminating an unexpected pregnancy under this view of the role of human agency im conception. ${ }^{94}$ To some people, abortion enables them to abide by their original intention that the birth of a child not result froin ongoing heterosexual intimacy. As Rosalind Petchesky points out, they feel that the risk of pregnancy should never prohibit women and men from engaging in the sex:

A clear feminist vision, an alternative culture of sexuality embracing passion and play as well as love, ... a revolution in women's social place and in the relations of reproduction is impossible without a "new morality" of sex and love. . . A Abortion ... has to do with women's sexual and moral autonomy as much as their physical integrity. . . . [W] may posit that sexual self-expression is itself a basic human need so allied to a person's physical and emotional well-being as to constitute an aspect of "health" in the widest sense. 95

All of these attitudes einphasize only part of the life-giving process-either the role of human agency or the role of natural forces-as a premise for action. The degree of einphasis on huinan responsibility affects one's view of whether the fetus deserves primary, equal, or relatively minor weight when balanced with other concerns in the event of an unwanted pregnancy. It is difficult, if not impossible, to tell whether a person's attitude toward sex determines her view of the value of fetal life or vice versa. But a person's views on both subjects mutually reinforce the other view and together show a pattern of individual coinmitınent. Individuals usually will feel "right" and "justified" in the coinmitınents they accept, and they often find opposing views incoinprehensible, if not foolish or irresponsible. ${ }^{96}$

In my mind, individuals should value human agency in conception enough that abortion is altogether unacceptable, except when pregnancy

93. Id. at 338,348 .

94. Id. at 365, 369; Callahan, supra note 81, at 292.

95. R. PETCHESKY, supra note 5, at 391, 392, 393; see Callahan, supra note 81, at 288; Luker, supra note 4 , at 40.

96. See R. PETCHeSKY, supra note 5, at 372 ("For the liberal it is not the woman who gets an abortion who is 'selfish' but the one who doesn't-when she is too young or too poor or too 'incompetent.' "); Cahill, supra note 42, at 272 ("The decision to continue a pregnancy might be construed as a decision by the stronger to assume burdens that would otherwise fall on the most defenseless."); Luker, supra note 4, at 33; Ooms, supra note 56, at 174-75. 
endangers a woman's life or is the product of rape or incest. (Since the physical and psychological violation of human agency inherent in rape and incest is incompatible with attributing noral responsibility to a woman for the conception of a developing fetus, I cannot condemn her if she chooses to abort.97) For a woman to carry a fetus to term and for a man to share the burdens of pregnancy and childbearing is the better, more responsible, inore fulfilling commitment for human beings to make. ${ }^{98}$ However, if keeping the baby is not possible, the woman should plan to give the baby up for adoption rather than abort the fetus. ${ }^{99}$ And we should enploy all methods of moral power-writing, speaking, rebuking, listeming, encouraging - to persuade others to act responsibly with regard for the beginnings of human life.

Individuals who value a fetus the same as a born human being often feel strongly that the political community should enforce their value. They point out the danger of valuing life differently because of its degree of dependency or level of developinent, and they discuss the distinction between liberty and license in society. ${ }^{100}$ Some think that protecting the fetus with political power will reinforce the persuasive inethods of moral power. ${ }^{101}$ This view, however, fails to recognize that political enforcement interferes with the operation of moral power in the abortion decision because of the importance of individual agency in moral conduct. The pointed threat of coercion backing the expression of pro-life views in the United States today derails the inoral debate, masks the insights of the anti-abortion perspective, and liampers its persuasive potential.

Some individuals who oppose abortion feel so strongly about protecting the fetus that they do not care about the possible lack of commitment of the fetus' fatlier and motlier to the creation of their child. These individuals would force a woman to give birth witlout regard to the adverse effect of coercion on individual moral responsibility because of their

97. Contra Meehan, supra note 3, at 163-64 ("These problems are not the children's fault; we should not blame the children or punish them for the failure or crimes of others.").

98. I would suggest further that confining sexual desires to the expression of attraction, care, and emotional commitment in a marriage relationship is a happier, healthier choice for human beings, all concern for pregnancy aside. Others disagree. See supra note 95 and accompanying text.

99. Although giving a baby up for adoption can be traumatic, it also offers many benefits for the child and the new family. As one commentator notes: "A nonfamilial, nonpossessive appeal to continue a pregnancy can be made in order to give a new innocent life its chance to join the human family and to be reared by those ready and able to enjoy the privilege." Callahan, supra note 81 , at 288,293 . Unfortunately for all concerned, some minority women may not have the option to give their babies to eager, caring adoptive parents. I am hopeful such a situation is not prevalent and will not last.

100. M. Glendon, supra note 25, at 37; B. NAthanson, supra note 3, at 259-60; Callahan, supra note 81, at 296; Meehan, supra note 3, at 151-52.

101. M. Glendon, supra note 25 , at 62 ; Callahan, supra note 81 , at 301. 
confidence in the immorality of abortion. Mill describes (and criticizes) a similar attitude in his essay, On Liberty:

It is the duty of governments, and of individuals, to form the truest opinions they can; to form them carefully, and never impose them upon others unless they are quite sure of being right. But when they are sure (such reasoners may say), it is not conscientiousness but cowardice to shrink from acting on their opimions, and allow doctrines which they honestly think dangerous to the welfare of mankind, either in this life or in another, to be scattered abroad without restraint $\ldots .102$

Although one may agree fully with pro-life forces in the moral condemnation of abortion, it is not necessary to then agree that coercing birth is the appropriate response. The perception of abortion as a harm of the inost abhorrent kind-equivalent to inurdering a born huinan being - depends on rehgious or moral commitments ${ }^{103}$ that emphasize the role of human agency in conception and value the fetus as a developing human being. Neither of these commitments can be coerced effectively; they are only ineaningful if produced by careful, individual reflection and affirmation aided by private and public discussion. As Professor Mary Segers writes: "[I]t is not a departure from the values of liberalism to hold that individuals can be taught, encouraged, educated, exhorted, urged, entreated, and persuaded - but not legally coinpelled - to use their freedom (including reproductive freedoin) wisely and with due care for others." 104

The withdrawal of pro-life views from the pohitical arena probably wonld not cause a revolution of moral consciousness and fewer abortions. Individual agency means the freedom to make both wrong and right choices. But individual agency also ineans that everyone recognizes where full responsibility for wrong choices lies-with the individual.

As previously discussed, ${ }^{105}$ attitudes of superiority, contempt, or separation shonld not follow a judgment of right and wrong on the abortion issue. After explaining and encouraging an anti-abortion position, people who oppose abortion have "an obligation to respect the moral autonoiny of individual women regardless of their final decisions." 106

102. J.S. MiLL, supra note 22, at 87.

103. See R. PETCHESKY, supra note 5, at 331; Abernethy, supra note 85, at 132; supra notes 82 96.

104. Segers, supra note 5, at 251.

105. See supra text accompanying note 24 .

106. Segers, supra note 5 , at 251. 


\section{B. Preventing Abortion Does More Than Prevent Harm}

American law declines to coerce individuals into making substantial sacrifices for others without sufficient evidence of a freely considered commitment to make the sacrifices. Unless a statute creates an enforceable duty to care for another, none exists without the voluntary assumption of a fiduciary or contractual relationship. In Jones v. United States, ${ }^{107}$ a woman who had complete custody of her friend's baby for over ten months following the baby's birth was convicted of involuntary manslaughter when the baby died of severe malnutrition and neglect. The court of appeals overturned her conviction because the trial judge had not instructed the jury that they must find beyond a reasonable doubt that Mary Jones had a legal duty to supply food and necessities to the infant. 108 The court of appeals describes the circumstances under which individuals may be held to a legal duty to care for others:

One can be held criminally liable: first, where a statute imposes a duty to care for another; second, where one stands in a certain status relationship to another; third, where one has assumed a contractual duty to care for another; and fourtl, where one lias voluntarily assumed the care of another and so secluded the helpless person as to prevent others from rendering aid. 109

Because no legal duty to aid others attaches without evidence of individual commitment, an imdividual can pass a stranger bleedimg in the gutter without lifting a finger to help and have committed no tort ${ }^{110}$ or pumishable crime, even if that injured person dies. Government does not fail to use political power to punish this kind of behavior because of uncertainty about what the individual should do or because of a diversity of opinions about whether the giving of aid is right. Almost everyone would agree that right conduct for the person passing by would be to do what ever she or he could to save the injured person's life. However,

107. 308 F.2d 307, 310 (D.C. Cir. 1962). I am indebted to Jay Brown's suggestions and the aid of his paper, Emergency Aid as a Claim of Right: A Criticism of Criminal Good Samaritan Statutes (1989) (unpublished manuscript available from the author), for the information regarding Good Samaritan statutes included in this section. After completing this Note, I discovered an excellent article discussing abortion restrictions as Good Samaritan laws. I recommend that much more thorough discussion to the interested reader. Donald Regan, Rewriting Roe v. Wade, 77 Mich. L. REv. 1569 (1979).

108. Id. at 311 .

109. Id. at 310 .

110. RESTATEMENT (SECOND) OF TORTS $\$ 314$ comment c (1965) ("[O]ne human being, secing a fellow man in dire peril, is under no legal obligation to aid him, but may sit on the dock, smoke his cigar, and watch the other drown."). Two states, Vermont and Minnesota, have bypassed the common law with duty to aid statutes as follows: "A person who knows that another is exposed to grave physical harm shall, to the extent that the same can be rendered without danger or peril to himself ... give reasonable assistance to the exposed person . . . " VT. STAT. ANN. tit. 12, 519 (1973); see also MINN. STAT. $\$ 604.05$ (1988). 
recognition of the importance of individual agency in assuming responsibility for others' welfare makes the futile nature of Good Samaritan laws apparent. ${ }^{111}$ If an unfeeling passer-by could escape without detection, then she probably would, and a coinpassionate passer-by will act from genuine concern not fear of punishment.

Even assuming the harm in abortion is as grave as the harm in murder, one must recognize that preventing abortion involves much more than preventing inurder-it coerces substantial, prolonged sacrifices in another's behalf. ${ }^{112} \mathrm{~A}$ woman, $\mathrm{m}$ giving her body and its resources to the developinent of another body, makes a sacrifice that takes its toll on her physical, emotional, and often financial, health during pregnancy and afterward. If the mother alone or with the father ${ }^{113}$ decides to keep the child, then they assume life-spanning responsibility for someone else's well-being to which they inust attend regularly. The mother and father may need to make substantial changes in their relationship to each other and to others to ineet this responsibility. Their sense of control over their lives will be permanently affected. Future plans and goals for personal development inay be prolonged, if not permanently adjusted. If the option of adoption is available, and the parents choose to give up the baby for adoption, they will probably feel emotional loss and perhaps guilt for soine time. Eacli parent inay wonder for the rest of his or her life what has become of the child. ${ }^{114}$

111. See A.D. Woozley, $A$ Duty to Rescue: Some Thoughts on Criminal Liability, 69 VA. L. REv. 1273, 1290 (1983) (four principled objections to Good Samaritan laws: "[1] concern with selective enforcement of the law, [2] fear that a legal sanction diminishes the moral virtue of rescuers, [3] concern with an infringement of civil liberties, and [4] fear of a 'slippery slope' once an omission is treated as a criminal act").

112. R. Petchesky, supra note 5, at 375 ("Maternity, if chosen, is not servitude; it is in many ways pleasant and satisfying, socially as well as personally. But it is at the same time a service that every childbearing woman performs for others ... that requires an irreducible physical burden: the renunciation of bodily health and well-being for many months, perhaps with permanent physical consequences...."); Callahan, supra note 81, at 297 ("In all pro-life positions, the problem remains that one is also going to inflict suffering by supporting the claims of the fetus to be protected by a change in the law."); Segers, supra note 5, at 231-32.

113. Giving the woman full agency to abort or not requires that the father be given a fair opportunity to renounce his responsibility to the child either during the period when the woman can safely abort or later when the baby can be adopted. As long as the woman has the choice to avoid parenting, she cannot fairly strap him to that responsibility without similar deliberation and consent on his part. If he does not consent, then the woman may still decide to give birth and have the baby adopted or keep the child herself.

114. R. PETCHesky, supra note 5, at 346 ("The experience of going through a full-term pregnancy, bearing a child, and giving it up for adoption is punitive and traumatic for a woman because the relationship by then is real; it exists."); Callahan, supra note 81, at 293 ("The sorrow of seeing one's own fiesh and blood, a family member, given away to outsiders and an unknown fate becomes too hard to face."). 
Coercing birth resembles a Good Samaritan law, particularly when safe, effective, relatively inexpensive means for terminating a pregnancy exist as they do today in the United States. The majority in Roe v. Wade were well aware of the burdens of childbirth when they decided abortion could not be prevented appropriately with political power. ${ }^{115}$ We simply do not coerce that level of commitinent to others. We rely on caring, responsible impulses among people bound together by something other than coercion to bring out the best in us. ${ }^{116}$

However, anti-abortion regulations differ from a Good Samaritan law in sonie ways. Whereas an uncompassionate passer-by can avoid helping an injured person by doing nothing, a pregnant woman nuust destroy the fetus to avoid helping it. Also, a mother and father are directly responsible for the fetus' existence, whereas a passer-by did not create the injured individual. While these distinctions remforce my conviction that abortion is not morally justified, they fail to persuade me that a pregnant woman should be forced to nourish the fetus.

Another natural objection to analogizing anti-abortion regulations to Good Samaritan laws follows from the recognition that we use political power to prevent or punish the abandonment or killing of a born infant, without regard for the behefs of the offender and whether our actions will encourage or discourage a change in those behefs. ${ }^{117}$ All of the observations about dependency, sacrifice, commitment, and the effect of coercion that apply in discussions about unwanted pregnancies-except for the pecuhar physical symbiosis between woman and fetus im pregnancy-apply to newborns and children. Yet none of us would say that a parent should be allowed to resort to the "safe, effective and relatively inexpensive" ineans of avoiding parental responsibility by abandoning or killing an infant.

115. 410 U.S. 113, 153 (1973) ("The detriment that the State would impose upon the pregnant woman by denying this choice altogether is apparent. . . . Maternity, or additional offspring, may force upon the woman a distressful life and future. Psychological harm inay be imminent. Mental and physical hcalth may be taxed ...."); cf. Callahan, supra note 81, at 298 ("However, when suffering cannot be relieved, or when it is freely taken on for the sake of others, the suffering will not be meaningless for those who live in basic trust.") (emphasis added).

116. Segers, supra note 5 , at 231.

117. Rosalind Petchesky suggests using the capacity for conscious individuation from others as a moral touchstone to distinguish treatment of born infants from fetuses. R. PETCHESKY, supra note 5 , at 345-47.

Justice Stevens wrote in Thornburgh v. American College of Obstetricians and Gynecologists:

[I] $t$ seems to me quite odd to argue that distinctions may not also be drawn between the state interest in protecting the freshly fertilized egg and the state interest in protecting the 9-month-gestated, fully sentient fetus on the eve of birth. Recognition of this distinction is supported not only by logic, but also by history and by our shared experiences.

476 U.S. 747, 779 (1986) (Stevens, J., concurring) (footnotes omitted). 
One important difference between responsibility to a born luman being and a fetus lies in the degree to which we can say the individual has assumed responsibility for the other's welfare. Some pro-cloice persons believe that a conscious decision to continue a pregnancy, a choice inore deliberate than simply conception, is required before a man and woman become subject to an enforceable moral obligation. As Professor Lisa Cahill describes, pro-life persons believe that conception brings with it enforceable obligations to nurture the growing life:

Of particular relevance to the abortion dilemma is the fact that duties or obligations can bind humans to their fellows in ways to which they have not explicitly consented. Such obligations originate simply in the sorts of reciprocal relatedness that constitute being human. The mother-fetus relation is characterized by obligations of this sort, as are all parent-child relations. ${ }^{118}$

Pro-life persons may retain the importance of consent in creating legal obligations if they view the clioice to engage in leterosexual relations as an assumption of possible parenting responsibilities. If the political commumity protects fetal life with political power, as it does with respect to born infants, then government sends a clear message to women and men that whenever they liave sex, they assume the risk of responsibility for a third person's welfare. The political community sends the message that because it values fetal life the same as a born human being, the important clioices regarding parenting concern when, with whom, and under what life circumstances to have sex, not whether or not to continue a pregnancy.

To most people who have a religious or moral commitment to respect the role of liuman agency above the role of natural forces in conception, ${ }^{119}$ this message is self-evident. ${ }^{120}$ But the truth of the message does not justify backing it with political power. To those who do not profess a strong religious or moral commitment to the life-giving potential in sex, the message sounds tyrannical. It threatens grave penalties for not clianging their bellavior about deeply intimate, life-spanning concerns-sex and family-without respect for a voluntary process of cliange in their attitudes. As Professor Virginia Abernethy posits:

In the "abortion debate," adherents of the right-to-life novement are attempting to force the behavioral consequences of their beliefs on others. The debate exists because a moral insight apparent to just a

118. Cahill, supra note 42 , at 265 .

119. See supra notes $82-91$ and accompanying text.

120. See supra notes 97-101 and accompanying text. 
portion of the citizenry has been infused into the political process and is being proposed as the law of the land.121

As a political coniniunity, will we settle for right conduct on such deeply significant matters or do we want individually chosen right conduct? If we prevent abortion with political power, undoubtedly sonie women will continue to exercise their individual agency and procure abortions either at great financial cost or at great risk to their own lives and health. ${ }^{122}$ Undoubtedly, other wonien will not be able to pay the price or will not take the risk, but instead will patiently or bitterly bear the child they would have aborted. However, no woman will have the opportunity to voluntarily reconsider whether they have assumed responsibility to give the fetus life when they conceived the fetus. True, sonie people might reconsider im spite of, or even because of, the coercion, but niany people will blame the coercive arm for the birth. ${ }^{123}$ As a result, the political community nray have more infants born but will have sacrificed the nioral growth of individuals in the process. ${ }^{124}$

More iniportant than utilitarian considerations for the good lost to society in preventing abortion-perhaps as much can be said for the good gained ${ }^{125}$-is the false niessage sent to women with unwanted pregnancies. Inappropriate external rewards or punishnients nıask the truth about full individual responsibility for exercising or not exercising

121. Abernethy, supra note 85, at 133; see also R. PeTchesky, supra note 5, at 378 ("Control over one's body ... [is] a positive and necessary enabling condition for full human participation in social and communal life.").

122. Webster v. Reproductive Health Servs., 109 S. Ct. 3040, $3077-78$ (1989) (Blackmun J., concurring and dissenting in part); Ooms, supra note 56, at 172-73.

123. See Ooms, supra note 56, at 173 ("The energies of the pro-choice movement would focus entirely on challenging, disrupting, or disobeying the law.").

Professor Hart writes:

[T] here is very little evidence to support the idea that morality is best taught by fear of legal punishment. Much morality is certainly taught and sustained without it, and where morality is taught with it, there is the standing danger that fear of punishment may remain the sole motive for conformity.

H.L.A. HART, supra note 39, at 58. But see Callahan, supra note 81 , at 301 (role of the law in educating and disciplining the emotions); supra note 25 .

124. Segers, supra note 5, at 235 (We inust have "a realistic sense of the limits of the criminal sanction ... [for] recriminalizing abortion will not achieve their intended effect of reducing the incidence of abortion and will result in more harm than good."); see also R. PETCHESKY, supra note 5 , at 350 ("WW]hat is going on here is a struggle, not over the contents of the womb, but over the meaning of maternity and the competence of adult women to exercise judgment.").

125. The positive educational effect of the preventive laws on soine, see M. GLENDoN, supra note 25 , at 60 , or the good saved in the lives of the born infants are possible exainples of the good im preventing abortion. For recognition of the harm done by present permissive abortion laws, see $i d$. at 34-35 ("filtered through the communications inedia to popular consciousness, the statement by the highest court of the land that a fetus is not a 'person' las great potential for being misunderstood"); Ooms, supra note 56, at 172 ("[U]ndoubtedly, sucl liberalization of the law did contribute to the rise in the number and the rate of abortion and has clianged attitudes even furtler."). 
the capacity to grow in wisdom, self-control, and love. ${ }^{126}$ But if an individual is truly and fully responsible to her own conscience for her actions on a particular matter, the most important effect among other effects of right or wrong conduct will be internal. When the political community refrains from imposing external punishments on the abortion issue, it allows the truth about individual responsibility for morally good behavior in sexual and family relations to become real and powerful in individual lives.

Admittedly, the "individual responsibility" message subordinates the effect of abortion on the fetus to the woman's moral choice. That is, the message says that the political community values human agency on the abortion issue, with its prize and price, more than it values fetal life. I, for one, want the prize-full individual responsibility for family relationships with the moral development that individual responsibility brings-enough to suffer the price-that sometimes individuals will settle for less in their moral commitments and some fetuses will never be born.

\section{CONCLUSION}

By refraining from using pohitical coercion to prevent abortion, those who find abortion abhorrent do not participate in the sin of those who choose to abort. Rather, they make a judgment about the limits of political coercion and our coininon commitment as a political commumity, and about the extent of individual responsibility to conscience, to others, and to God rather than to government. Making this judgment enables pro-life advocates to commit themselves fully to the more difficult, but more worthwhile, task of winning hearts and minds to a better way of life.

Some Supreme Court Justices have revived the question of which government mstitution should make the judgment about the limits of pohtical coercion in regulatimg abortion. In Webster $v$. Reproductive Health Services, four Justices express with varying degrees of conviction

126. Although concluding that laws will aid rather than hinder the process, Sidney Callahan recognizes the possibility for growth in wisdom, self-control, and love: "Educating and disciplining the emotions are seen as necessary to character development, for emotional growth is possible. A woman, for instance, who may not want a child can change her emotional reactions through reflection, self-mastery, and the power of love." Callahan, supra note 81 , at 301; see also R. GRANT, supra note 21, at $45-48$ (describing Locke's understanding of individuals' ability to "educate their desires" and "submit themselves to self-government" in the cxercise of freedom).

Again, I emphasize that recognizing others' decision regarding abortion as wrong and damaging to their inoral growth does not justify stereotyping them as "carcless, immoral, and selfish." See R. PETCHESKY, supra note 5, at 370 (discussing inappropriate stereotyping of women who abort); see also supra notes $24,105-06$ and accompanying text. 
their view that, contrary to the decision in Roe v. Wade, the state legislatures and not the Supreme Court are the appropriate imstitutions to decide the limits of abortion regulations. ${ }^{127}$ Unlike the dissenting Justices, Chief Justice Rehnquist and Justices White, Kennedy, and Scalia, suggest (but do not expressly hold) that the Constitution does not put abortion "beyond the reach of the democratic process."128

However, the fourteenth amendment, in combination with the characteristics bestowed on the Supreme Court by article III of the Constitution $^{129}$ and the power bestowed by the tradition of judicial review, requires the Court to assume watchdog responsibilities in the federal system, ensuring that states do not "deprive any person of hfe, hiberty, or property, without due process of law."130 While some commentators, such as John Hart Ely, argue that "due process" means little more than procedural fairness in the operations of democratic government, 131 " $\mathrm{hb}$ erty" is more than a word in the due process clause of the fourteenth amendment passed in 1868. Liberty, or mdividual agency, is one of the "unahenable rights" for which early Americans fought and died in a bloody revolution. They beheved that "whenever any Form of Government becomes destructive of these ends, it is the Right of the People to alter or abohsh it . . ."132 Liberty is a foundation principle in our form of government, a right we believe pre-exists government and survives its abohtion. Alexander Hamilton defended the judiciary created by article III of the Constitution as a protector of liberty not only when faced with a specific violation of the Constitution, but also when faced with "unjust and partial laws."133 Justice Douglas quotes a 1905 Supreme Court case

127. Webster v. Reproductive Health Servs., 109 S. Ct. 3040, 3040-58, 3064-67 (1989) (Rehnquist C.J., White, J., Kennedy, J.) (Scalia, J., concurring). For quotes of these Justices' opinions regarding the importance of the legislative process on issues such as abortion, see supra note 17 . The dissenting Justices in Roe $v$. Wade express similar concerns about the relationship of the legislative and judicial processes: "[T]he conscious weighing of competing factors that the Court's opinion apparently substitutes for the established [rational relation] test is far more appropriate to a legislative judgment than to a judicial one." 410 U.S. 113, 173 (1973) (Rehnquist, J., dissenting); see also id. at 222 (White, J., dissentimg) ("I find no constitutional warrant for imposing such an order of priorities on the people and legislatures of the States.").

128. Webster, $109 \mathrm{~S}$. Ct. at 3058.

129. Article III grants life tenure and an undiminishable salary during their term in office to all Supreme Court Justices, as well as to judges of the lower federal courts. U.S. CoNSr. art. III, $\S 1$.

130. U.S. CONST. amend. XIV, §1.

131. Ely, supra note 15, at 935 ("But 'due process' generally guarantees only that the inhibition be procedurally fair and that it have some 'rational' connection-though plausible is probably a better word-with a permissible government goal.").

132. The Declaration of Independence para. 2 (U.S. 1776). For a longer inclusive quote from the Declaration of Independence, sec supra text accompanying note 25.

133. Hamilton argues:

But it is not with a view to infractions of the Constitution only that the independence of the judges may be an essential safeguard against the effects of occasional ill humors in the 
suggesting a similar idea in his Roe concurrence: "There is, of course, a sphere within which the individual inay assert the supremacy of his own will and rightfully dispute the authority of any human governinent, especially any free government existing under a written constitution, to interfere with the exercise of that will." 134 Recognizing the inportance of liberty does not answer immediately the question whether women ought to be free to abort fetuses, but it does recommend greater consideration of the imphications of political coercion on the question than suggested by a narrowly procedural interpretation of the due process clause.

James Madison expressed concern for the inajority tyranny that can result from the (albeit procedurally fair) operations of democratic government. In The Federalist No. 10, he recominends a large republic to lielp alleviate the danger of inajority tyranny. ${ }^{135}$ Altliougli a large republic may suffice to make majority tyranny difficult on the national level, the lessons of slavery, civil war, segregation, and racial discrimination deinonstrate tlie dangers of majority tyranny on the state level. The fourteentli amendment was passed in response to tliese crises, and should be interpreted as conferring authority on the Supreme Court to prevent majority tyranny on the state level similar to its power to prevent majority tyranny at the national level. ${ }^{136}$ Consequently, contrary to the plurality's intimations in Webster, the Supreme Court has a duty to consider whether state restrictions on abortion anount to majority tyranny.

The Supreine Court einbraced that duty when in Roe v. Wade it thoroughly considered and negatively answered the question whether political power can be used appropriately to prevent abortion before fetal viability. ${ }^{137}$ Political power cannot appropriately be used to prevent

society. These sometimes extend no farther than to the injury of the private rights of particular classes of citizens, by unjust and partial laws. Here also the firmness of the judicial magistracy is of vast importance in mitigating the severity and confining the operation of such laws.

The Federal1st No. 78, at 470 (A. Hamilton) (C. Rossiter ed. 1961).

134. Doe v. Bolton, 410 U.S. 179, 213-14 (1973) (quoting Jacobson v. Massachusetts, 197 U.S. 11,29 (1905)).

135. The Federalist No. 10, at 83 (J. Madison) (C. Rossiter ed. 1961).

136. See supra text accompanying note 133. Robert Bork points out that "[m]ajority tyranny occurs if legislation invades the areas properly left to individual freedom," whereas "[m]inority tyranny oceurs if the majority is prevented from ruling where its power is legitimate." Bork, Neutral Principles and Some First Amendment Problems, 47 IND. L.J. 1, 3 (1971). Apparently, on the abortion question some of the Justices fear mimority tyranny at the hands of the Supreme Court more than majority tyranny at the hands of state legislatures.

137. 410 U.S. 113, 159-60 (1973). For a more thorough discussion of the legitimacy of Roe's constitutional grounding, see Ely, supra note 15 (bad decision without adequate constitutional grounding), and Laurence Tribe, Foreward: Toward a Model of Roles in the Due Process of Life and Law, 87 HARV. L. REv. 1 (1973) (although Roe has its problems, it is a step in the right direction). See also Walter Dellinger \& Gene Sperhing, Abortion and the Supreme Court: The Retreat From Roe v. Wade, 138 U. PA. L. REv. 83 (1989) (Webster discounts Roe's principles without adequate expla- 
harms that without moral or rehigious commitments are not perceived as harms. ${ }^{138}$ Further, even if all agreed that abortion causes a harm similar to murder, coercing involuntary sacrifices for others of the magnitude involved im a nine-month pregnancy has no precedent in our society. ${ }^{139}$ The choice to adhere to the principle that sexual relations entail the risk of parenting obligations is a value judgment that requires individual reflection and moral commitment. Women should not be coerced imto assuming the responsibility of giving birth to children if they reject the value judgment that enjoying sexual intimacy necessarily brings with it that potential responsibility. ${ }^{140}$ With these minor adjustments in the analysis, the decision in Roe is mandated by our structurally limited form of government ${ }^{141}$ and is enforced appropriately by the Supreme Court against the states through the due process clause of the fourteenth ainendment.

Kimberly Sharron Dunn

nation); William Van Alstyne, Closing the Circle of Constitutional Review from Griswold v. Connecticut to Roe v. Wade: An Outline of a Decision Merely Overruling Roe, 1989 DukE L.J. 1677 (responding to Dellinger and Sperling's defense of Roe as a necessary extension of Griswold).

138. See supra notes 82-104 and accompanying text.

139. See supra notes $107-16$ and accompanying text.

140. See supra notes 118-21 and accompanying text.

141. Although he may not consider the analysis convincing, John Hart Ely suggested that the "system of government contemplated by the Constitution" might support a "constitutional right to an abortion" when he pointed out that the Court did not make use of that justification in Roe, as it had when it rccognized a fundamental right to interstate travel. Ely, supra note 15, at 927-28. 